\title{
Kajian Psikologi Positif Konsep Ikigai Pada Kaisar Akihito Dalam Manga Akihito Tennou Monogatari
}

\author{
Aqiilah Bilqiis Salsabiil Harahap, Yusida Lusiana, Heri Widodo
}

Program Studi Sastra Jepang, Universitas Jenderal Soedirman, Indonesia e-mail: aqiilah.harahap@mhs.unsoed.ac.id

\begin{abstract}
The aim of this study is to explain the relationship between the concept of Ikigai and eudaimonic happiness also with the psychological well-being of Emperor Akihito. This research is a descriptive qualitative type. The data were collected using literature study techniques which are sourced from Akihito Tennou Monogatari manga. The results found that the concept of Ikigai in Emperor Akihito, both in the form of characteristics and Ikigai pillars, all reflected Aristotle's eudaimonic happiness because it was in accordance with the virtue of an emperor, which is being a good emperor with the ability to embrace all his people and establish positive relationships with the international world. The concept of Ikigai also reflects six aspects of Ryff's psychological well-being, that is consist of 1) self-acceptance, 2) positive relationships with others, 3) autonomy, 4) environmental mastery. ), 5) purpose in life, and 6) personal growth. The conclusion is that Emperor Akihito was able to achieve eudaimonic happiness as well as psychological well-

being by being a good emperor as a form of his Ikigai.
\end{abstract}

Keywords:

Eudaimonic happiness; Emperor akihito; Ikigai; Psychological wellbeing

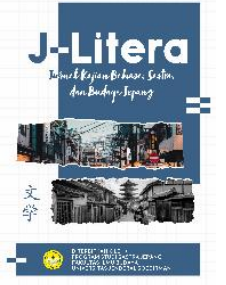

Article Info:

First received:

20 April 2021

Available online:

28 May 2021

\section{PENDAHULUAN}

Istilah Ikigai secara umum merujuk pada kesenangan dan makna kehidupan. Ikigai dalam bahasa Jepang berasal dari dua kata yaitu, 生き (iki) yang berarti hidup dan 甲斐 (gai) yang berarti nilai. Dengan demikan, secara harfiah Ikigai dapat dimaknai sebagai "nilai hidup". Adapula yang mengartikan Ikigai sebagai "alasan bangun di pagi hari". Pemaknaan tersebut ada sangkut-pautnya dengan budaya bangun pagi di Jepang yang sudah sangat mengakar sejak zaman kuno (Mogi, 2018:25).

Dalam bahasa Jepang sendiri, kehidupan memiliki dua istilah yang cukup mirip namun memiliki arti yang berbeda yaitu, 人生 (jinsei) dan 生活(seikatsu). Kedua istilah tersebut samasama memiliki makna"kehidupan", tetapi fokusnya berbeda. Kata 人生 (jinsei) merujuk pada kehidupan manusia selama ia hidup, mulai dari lahir hingga meninggal dunia (lifetime). Sedangkan kata 生活 (seikatsu), mengacu kepada kehidupan sehari-hari atau daily life. Prof. Hasegawa Akihiro menjelaskan bahwa istilah Ikigai lebih tepat jika dikaitkan dengan 生 活 (seikatsu). Jadi, peranan Ikigai bukanlah pencarian "nilai hidup" secara utuh sejak dilahirkan hingga kematian namun, lebih kepada "nilai" seseorang dalam kehidupan sehari-harinya (Ikigaitribe, 2019).

Konsep Ikigai memang tidak dapat dipisahkan dari kehidupan orang Jepang. Peranan Ikigai sangat penting dalam memotivasi diri bagi bangsa Jepang yang memang dikenal memiliki budaya kerja keras agar dapat memperoleh kebahagiaan serta kesejahteraan hidup. Pemaknaan Ikigai yang sering kali dikaitkan dengan konsep kebahagiaan khas Jepang, membuatnya sangat cocok apabila ditelaah berdasarkan kajian psikologi positif.

Kajian psikologi positif dipelopori oleh Seligman. Inti pembahasannya yakni seputar berbagai sisi positif dalam diri manusia serta bagaimana pengaruh hal tersebut terhadap keberhasilan mencapai tujuan hingga melahirkan kebahagiaan (Jusmiati 2017: 360).

Pembahasan mengenai Ikigai cukup penting mengingat semakin berkembangnya zaman, tekanan serta tuntutan hidup semakin bertambah hingga dapat memicu stres berkepanjangan. Apabila individu tidak dapat mengatasinya dengan benar, maka akan 
menimbulkan depresi atau bahkan kematian. Dengan demikian, perlu pemahaman yang baik terkait konsep Ikigai. Meskipun Ikigai termasuk konsep filosofis dan mengandung ambiguitas, melalui kajian psikologi positif diharapkan masyarakat bisa lebih mudah untuk memahami dan mengimplementasikannya.

Penelitian terkait Ikigai sebelumnya telah banyak dilakukan diantaranya oleh Park (2015) berjudul "Sense of Ikigai (reason for living) and Social Support in Asia-Pacific Region". Dalam penelitian tersebut ditemukan bahwa, baik dukungan emosional ataupun dukungan penilaian memiliki dampak terhadap persepsi harapan hidup sehingga bisa dikatakan penerimaan pujian dan pengakuan dari orang lain menjadi faktor yang berkontribusi terhadap rasa Ikigai di negara Asia Pasifik (Park, 2015: 191). Sementara itu, Eller (2016) dalam penelitiannya yang berjudul "Ikigai and Higher Education: A Review of The Literature" menemukan fakta bahwa, Ikigai pada orang Jepang cenderung berubah seiring bertambahnya usia serta mendapat pengaruh dari pendidikan yang ia peroleh. Berbeda halnya dengan Bilash (2019) lewat penelitiannya yang berjudul "Study Abroad, Transformation, and Ikigai: A Case Study"menyimpulkan bahwa, Ikigai turut memainkan andil terkait semangat hidup seseorang. Dalam penelitian tersebut, Bilash menyelidiki bagaimana evolusi yang dialami Kuni (nama samaran), orang Jepang yang bekerja di kota kecil Hokkaido sebagai guru bahasa Inggris selama 10 tahun. Hasil yang diperoleh yakni, Ikigai sangat mempengaruhi semangat Kuni ketika ia mengajar dimana dengan mengajar ia mendapat nilai-nilai kehidupan yang diberikan para siswanya.

Di antara penelitian terdahulu yang telah dipaparkan di atas belum ada penelitian khusus mengenai Ikigai dengan objek seorang pemimpin negara secara spesifik yakni pemimpin negara Jepang atau dalam hal ini seorang kaisar (tennou). Oleh karena itu, penelitian ini bertujuan untuk mengelaborasi tentang Ikigai salah seorang kaisar Jepang (tennou) sebagai sosok yang menjadi panutan serta paling berpengaruh di negara Jepang.

Tekanan serta tuntutan hidup bagi setiap individu tentunya beragam. Hal tersebut salah satunya dipengaruhi oleh status sosial individu bersangkutan. Semakin tinggi status sosial yang dimiliki, maka akan semakin tinggi pula tekanan juga tuntutan hidupnya. Pemimpin negara merupakan salah satu pekerjaan yang mengemban tanggung jawab besar, sehingga tak disangsikan lagi mereka pasti memiliki tuntutan hidup yang tinggi. Tak terkecuali kaisar Jepang ke-125, Akihito. Kaisar yang baru saja turun takhta pada 30 April 2019 lalu ini disebut sebagai kaisar pertama selama 200 tahun kekaisaran di Jepang yang secara sukarela turun takhta. Hal ini beliau lakukan karena kondisi kesehatannya yang tak lagi bugar untuk mengemban tugas-tugas sebagai kaisar.

Kaisar Akihito merupakan sosok yang sangat dikagumi dan disayangi oleh banyak orang Jepang karena perhatiannya yang mendalam kepada rakyatnya. Perhatiannya itu tercermin melalui tindakannya pada tahun 1991, ketika gunung berapi di Nagasaki meletus Kaisar Akihito dan permaisuri berani melanggar norma kebangsawanan dengan berlutut untuk berbicara bersama para korban letusan gunung tersebut. Beliau juga tak segan untuk memperhatikan para penderita penyakit kronis seperti kusta dan sebagainya. Berawal dari kebiasaan Kaisar Akihito untuk berinteraksi dengan para penyintas bencana maupun dengan penderita penyakit inilah yang membuat beliau memutuskan untuk berperan serta sebagai diplomat. Meskipun, peran diplomat yang dilakukan olehnya bukanlah diplomat secara resmi, tetapi tindakan ini selain dinilai telah menghilangkan batasan-batasan dalam hukum kekaisaran di Jepang serta dianggap sebagai tindakan yang positif dalam membangun persahabatan dengan negara-negara lain.

Sebenarnya tindakan Kaisar Akihito dalam menggebrak hukum tradisional di Jepang bukanlah satu-dua kali saja. Beliau juga pernah melanggar aturan kekaisaran untuk tidak menikahi rakyat biasa. Sang istri sekaligus permaisurinya, Shoda Michiko adalah anak dari pengusaha penggilingan tepung yang bukanlah keturunan darah biru. Tak hanya itu, beliau juga pernah membuat pernyataan bahwa dirinya memiliki darah Raja Korea. Kedua tindakan tersebut merupakan pantangan yang tidak seharusnya dilakukan oleh seorang yang memiliki Takhta di Krisantenum. Selain itu, Kaisar Akihito dikenal pula sebagai seorang kaisar yang giat untuk meminta maaf pada negara korban kejahatan perang oleh Jepang di masa lalu, salah satunya adalah Cina. Beliau dan permaisuri kerap kali mengunjungi situs bekas Perang Dunia II untuk mendoakan arwah para korban baik dari pihak Jepang maupun negara lain. 
Kaisar Akihito juga merupakan sosok yang sangat mencintai ilmu pengetahuan terutama dalam bidang kelautan dengan objek ikan gobi. Beliau sangat aktif membuat makalah sejak masih menjadi putera mahkota sampai telah menjadi kaisar. Jumlah makalah yang telah beliau publikasikan terhitung sebanyak 27 makalah. Makalah-makalah tersebut semuanya membahas ikan gobi yang diterbitkan di Japanese Journal of Ichtiology. Judul makalah pertamanya adalah "On the Scapula of Gobiid Fishes" (1963) (Abdulsalam, 2018).

Berdasarkan latar belakang tersebut, akan sangat menarik apabila melakukan penelitian mengenai konsep Ikigai pada Kaisar Akihito. Sebagai seorang pemimpin pastilah Kaisar Akihito memiliki banyak tekanan dan tuntutan hidup maka di sinilah bagaimana peranan Ikigai dapat membentuk kehidupan positif untuknya. Terlebih, beliau merupakan seorang kaisar Jepang yang sifatnya tergolong unik diantara para kaisar lainnya (Abdulsalam, 2018).

Penelitian ini berfokus pada bagaimana keterkaitan konsep Ikigai baik berupa karakteristik maupun pilar Ikigai pada Kaisar Akihito dalam manga Akihito Tennou Monogatari mampu sejalan dengan kebahagiaan eudaimonis serta kesejahteraan psikologis dari sang kaisar.

Berdasarkan latar belakang yang telah dipaparkan, maka rumusan masalah dalam penelitian ini yaitu:

1. Apa saja konsep Ikigai yang terdapat pada Kaisar Akihito dalam manga Akihito Tennou Monogatari dan bagaimana hubungan konsep Ikigai tersebut dengan kebahagiaan eudaimonis milik beliau?

2. Apa saja konsep Ikigai yang terdapat pada Kaisar Akihito dalam manga Akihito Tennou Monogatari dan bagaimana hubungan konsep Ikigai tersebut dengan kesejahteraan psikologis milik beliau?

Adapun kerangka pemikiran dalam penelitian ini yakni sebagai berikut:

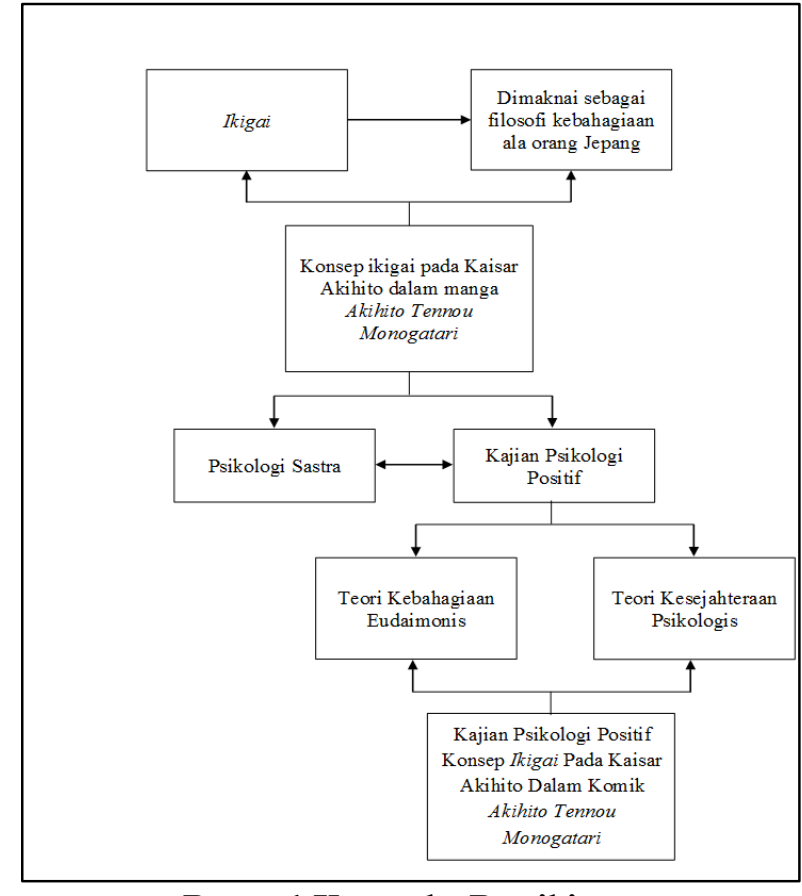

Bagan 1 Kerangka Pemikiran Sumber: Olahan Peneliti

\section{METODE}

Metode yang digunakan yaitu, deskriptif analitik. Deskriptif analitik dilakukan dengan cara mendeskripsikan fakta-fakta yang kemudian disusul dengan analisis. Secara etimologis deskripsi dan analisis berarti menguraikan. Meskipun demikian, analisis yang berasal dari bahasa Yunani, analyein ('ana' = atas, 'lyein' = urai), telah diberikan arti tambahan, tidak semata-mata menguraikan melainkan juga memberikan pemahaman dan penjelasan secukupnya. (Ratna, 2015: 53).

Dengan demikian, secara singkat penelitian ini dilakukan melalui tahapantahapan berikut :

1. Membaca manga Akihito Tennou Monogatari secara menyeluruh.

2. Mengelompokan data sesuai dengan permasalahan yang akan dianalisis. Data dalam hal ini berupa kutipan ataupun cuplikan peristiwa dalam manga.

3. Menganalisis data tersebut berdasarkan teori yang digunakan dalam penelitian. Hasil analisa disajikan dalam uraian deskriptif sesuai dengan fakta-fakta yang ditemukan.

4. Terakhir, dilakukan penarikan kesimpulan. 


\section{TINJAUAN PUSTAKA}

\section{A. Karakteristik dan Pilar Ikigai}

Kamiya Meiko dalam bukunya yang berjudul Ikigai ni Tsuite menjelaskan tentang karakteristik Ikigai. Berikut akan dipaparkan secara singkat:

\section{Ikigai dan Ikigaikan}

Seseorang yang memiliki Ikigai secara otomatis ia juga memiliki Ikigaikan. Ikigaikan dimaknai sebagai 'perasaan' Ikigai yang merujuk pada rasa senang seseorang dalam melakukan hal yang ia anggap Ikigai-nya. Misalnya, kisah Oka Kiyoushi (matematikawan Jepang) yang memiliki Ikigai berupa kegiatan penelitian matematika. Ia senang meneliti matematika layaknya rasa senangnya sewaktu kecil ketika bermain air dan menangkap serangga.

\section{Tidak Selalu Berupa Hal yang Menguntungkan}

Wujud Ikigai tidak melulu terkait sesuatu yang memiliki manfaat secara langsung dalam kehidupan seseorang. Bisa saja Ikigai tersebut berupa hal-hal yang remeh-temeh, tampak siasia, atau bahkan sangat mewah. Karakteristik Ikigai ini sama halnya dengan konsep "permainan" Huizinga ${ }^{1}$ (Kamiya, 2004:82).

\section{Ada Motivasi dalam Melakukan Ikigai}

Seseorang yang hendak melakukan kegiatan sejalan dengan Ikigai-nya maka ia memiliki motivasi atau keinginan untuk melakukan kegiatan tersebut. Misalnya, seorang petugas medis yang Ikigai-nya yaitu memberikan pertolongan medis ke luar negeri secara sadar menerima panggilan tersebut bukan hanya sebatas kewajibannya tetapi juga ia mampu melakukannya dengan senang hati (Kamiya, 2004: 82).

\section{Ikigai Bersifat Pribadi}

\footnotetext{
${ }^{1}$ Johan Huizinga seorang teoritikus budaya, sejarawan, dan filsuf asal Belanda yang pernah menulis buku berjudul "Homo Ludens" (1938). Dalam bukunya itu, Huizinga berpendapat bahwa manusia adalah makhluk yang secara naluriah ingin bermain baik anak-anak maupun orang dewasa.

${ }^{2}$ Seorang ahli Biologi, Zoologi, dan filsuf asal Estonia (https://kulturportal-west-ost.eu/biographien/uexkulljakob-johann-baron-von-2)
}

Ikigai tiap orang bersifat pribadi atau personal. Ikigai tidak dapat dibentuk dengan 'meminjam' atau 'meniru' milik orang lain (Kamiya, 2004: 82).

\section{Ikigai Membuat Seseorang Menciptakan Sistem Nilai}

Apabila seseorang memiliki beberapa Ikigai, ia akan mampu memikirkan mana di antara Ikigai tersebut yang lebih penting, sehingga dapat dikatakan bahwa ia mampu menciptakan susunan hierarkis sesuai dengan apa yang ia ingin prioritaskan terlebih dahulu (Kamiya, 2004: 83).

\section{Ikigai Membuat Seseorang Merasa Bebas}

Kamiya (2004:83) menjelaskan bahwa Ikigai layaknya sebuah kehidupan yang nyaman, yakni ketika seseorang menciptakan dunia pikiran yang bebas. Menurut Uexküll ${ }^{2}$ semua makhluk hidup memiliki karakteristik dunianya sendiri begitu pula dengan dunia manusia. Bila meminjam metafora dari Nyonya Lindberg ${ }^{3}$ dalam bukunya "Gift Form the Sea" (1995) seperti halnya kerang berkat proses sekresi dari tubuhnya, mereka membuat pelbagai bentuk, pola, serta warna yang berbeda. Begitu pula manusia yang tumbuh dalam lingkungan mereka masing-masing, dengan demikian manusia mampu menciptakan kehidupan yang sesuai untuk mereka layaknya kehidupan yang membuat mereka nyaman di dalamnya.

Berdasarkan hal tersebut ketika kita tahu betul hal apa yang bernilai dan apa saja yang seharusnya diutamakan maka akan tercipta kesatuan, keteraturan, juga harmoni. Hal ini yang akhirnya membentuk stabilitas bagi orangorang yang tinggal dalam dunia tersebut (dunia dengan Ikigai di dalamnya). "Keinginan akan stabilitas" dalam contoh ini pun tampaknya pada dasarnya hanya akan terlihat ketika ada

\footnotetext{
3 Penulis, penyair, dan istri perintis penerbangan terkemuka Charles Lindberg yang menulis kumpulan essai berjudul "Gift Form the Sea" (1995). Buku tersebut menceritakan mengenai arti kehidupan seorang wanita.

Lihat https://www.findagrave.com/memorial/22876/annespencer-lindbergh
} 
ketenangan dunia pikiran yang melampaui dimensi ekonomi dan sosial (Kamiya, 2004:83).

Sementara itu, Mogi Ken dalam bukunya The Book of Ikigai (2018:40) menjelaskan bahwa Ikigai dibentuk berdasarkan lima pilar, yakni :

\section{Chiisaku Hajimeru Koto (Awali dari hal kecil)}

Ikigai tercipta dari hal-hal kecil yang kita temukan sehari-hari. Misalnya saja, Ono Jiro seorang chef sushi terkemuka di mana Ikigai-nya adalah membuat dan menyajikan sushi terbaik. Ia mulai membangun Ikigai tersebut dengan halhal kecil terkait dengan membuat dan menyajikan sushi, mulai dari merancang wadah khusus yang cocok untuk bentuk restorannya, memperbaiki berbagai peralatan membuat sushi, dan sebagainya.

\section{Jibun kara no Kaihou (Bebaskan Dirimu)}

Konsep pembebasan diri merujuk pada keadaan seseorang yang jiwanya ringan tidak memiliki beban apapun layaknya seorang anak. Anak-anak pada dasarnya memiliki jiwa yang bebas, mereka tidak pernah memikirkan perihal pekerjaan, ataupun terikat oleh status sosial tertentu (Mogi, Ken 2018:68). Dengan demikian seorang anak tidak membutuhkan Ikigai agar dapat menjalani hidupnya dengan ceria, karena pikiran dan jiwanya secara alami belum tercemari hal-hal rumit yang dapat memicu stress atau tekanan hidup.

Melalu Ikigai, diharapkan seseorang mampu membebaskan diri sehingga dirinya merasa nyaman dan tenang dalam menikmati hidup. Pembebasan diri secara paradoks juga terkait dengan penerimaan diri. Kita dianggap telah melakukan pembebasan diri apabila kita telah menerima diri kita apa adanya dan membuang segala bentuk khayalan diri yang ada pada diri kita (Mogi, 2018:169).

3. Chouwa to Jizoku Kanousei (Keselarasan dan Kesinambungan)

Keselarasan dan kesinambungan tampaknya terlihat pada bagaimana musik dari Radio Taisho menyatukan para orang tua saat senam pagi. Ketika Radio Taisho diperdengarkan pada pukul 06.30 sekelompok paruh baya berkumpul untuk senam pagi bersama, dari sini tercipta interaksi di antara mereka. Tak sedikit dari para orang tua ini menjadikan aktivitas senam pagi bersama teman-temannya sebagai Ikigai mereka. Sehingga bisa dikatakan musik Radio Taisho berperan dalam menyatukan satu komunitas demi menjaga keselarasan dan kesinambungan (Mogi, 2018:30-31). Tak jauh berbeda dengan klub Radio Taisho yang memanfaatkan kesatuan komunitas untuk menguatkan motivasi diri, klub Shougi pun demikian. Klub Shougi yang beranggotakan para pekerja kantoran ini selalu meluangkan waktunya di pagi hari yang sibuk dengan bermain shougi di dalam komuter (Mogi, 2018:32).

4. Chiisa na Yorokobi (Kegembiraan dari HalHal Kecil)

Ikigai diperoleh dari kegembiraan terhadap hal-hal kecil. Seperti klub Radio Taisho yang membuat anggotanya gembira hanya dengan senam pagi bersama, atau para pekerja kantoran yang sejenak bisa bersantai dengan bermain shougi dalam perjalanan menuju kantor yang membosankan.

\section{5. "Ima Koko"ni Iru Koto (Hadir di Tempat dan Waktu Sekarang)}

Bangsa Jepang memang terkenal sebagai bangsa yang sangat menghargai keindahan dari sesuatu yang fana. Karena dengan menyadari bahwa sesuatu itu fana, maka secara otomatis kita akan menghadirkan diri di tempat dan waktu sekarang (Mogi, 2018:48).

\section{B. Kebahagiaan Eudaimonis Aristoteles}

Istilah eudaimonis berasal dari bahasa Yunani eudaimonia. Bagi bangsa Yunani eudaimonia berarti kesempurnaan; atau lebih tepat lagi, eudaimonia berarti "mempunyai daimon yang baik" dan yang dimaksudkan dengan daimon ialah jiwa (Bertens, 2018:109). Sehingga apabila diterjemahkan secara harfiah dalam bahasa Indonesia, eudaimonia berarti "memiliki jiwa yang baik".

Kebahagiaan menurut konsep eudaimonis dipopulerkan oleh Aristoteles (384-322 SM). Menurutnya, kebahagiaan adalah tujuan tertinggi yang dicari oleh manusia dalam hidupnya. Tujuan tersebut merupakan tujuan akhir yang dicapai oleh manusia dengan cara menjalankan fungsinya sebagai manusia dengan baik. Lebih tepatnya, konsep eudaimonia menurut Aristoteles mencakup keutamaan 
moral seperti keadilan, keramahan, keberanian, aktivitas intelektual, juga kinerja tinggi dalam kegiatan apapun. Misalnya, profesi (Huta, 2013: 202).

Para filsuf hedonis seperti Arisstipos, Epikuros, Hobes, Locke, dan Bentham meyakini bahwa well-being akan diperoleh manusia apabila ia bisa memaksimalkan aspek happiness dan terbebas dari kesusahan. Sebaliknya menurut filsuf eudaimonis, Aristoteles berpendapat bahwa well-being tidak melulu diperoleh dengan memenuhi segala keinginan pribadi. Karena tidak semua keinginan pribadi itu dapat mendatangkan happiness, ada pula yang berakibat buruk bagi diri seseorang. Maka, well-being berdasarkan pandangan Aristoteles akan dicapai apabila seseorang mampu hidup sejalan dengan 'daimon' atau nilai-nilai yang mereka anut.

Aristoteles berpendapat bahwa tujuan tertinggi manusia dalam hidupnya yakni mencapai kebahagiaan dengan kata lain eudaimonia. Dalam eudaimonisme, pencarian kebahagiaan menjadi prinsip yang paling pokok. Eudaimonia merupakan paham eksistensial yang merujuk pada keadaan objektif, yakni berkembangnya seluruh aspek atau dimensi kemanusiaan seseorang individu (misalnya, aspek emosional, aspek sosial, aspek moral, aspek rohani, dan lain sebagainya) (Tjahjadi, 2004: 41). Dengan demikian, dapat dikatakan bahwa tujuan tertinggi manusia dalam hidup yakni membuat dirinya atau jiwanya secara menyeluruh tumbuh dan berkembang, serta menjadi sebaik mungkin (Tjahjadi, 2004: 41).

Jadi dapat dimaknai bahwa hidup yang baik menurut pandangan Aristoteles bukanlah hidup yang bergelimang kesenangan atau kenikmatan, namun hidup yang ditandai oleh kesadaran dan direfleksikan sehingga berbuah makna dan kebijaksanaan; serta hidup di mana virtues yang unik telah didayabaktikan dengan penuh-bagi dirinya sendiri terlebih bagi masyarakat (Arif, 2016:20).

Virtues sendiri merupakan salah satu hal terpenting dalam konsep eudaimonia menurut Aristoteles. Virtues dapat diartikan sebagai kebaikan utama yang unik, fungsi utama, nilai utama, ataupun tujuan dari segala sesuatu. Contohnya, virtue dari garam yakni untuk menjadi asin. Kalau garam tidak dapat menjadi asin maka garam tersebut telah kehilangan virtue-nya sebagai garam, sehingga ia tidak lagi berarti maupun bernilai. Maka agar dapat menjadi garam yang virtuous garam haruslah bisa menjadi asin sesuai dengan tujuan dari garam itu sendiri (Arif, 2016:21).

Kata virtue sebetulnya merupakan terjemahan bahasa Inggris dari arete (bahasa Yunani) yang berarti keutamaan (Lorens dalam Yulanda, 2020: 94). Menurut Aristoteles manusia memiliki dua macam keutamaan, yakni: keutamaan moral dan keutamaan intelektual (Bertens, 2018:207). Berikut penjelasannya:

\section{1) Keutamaan Moral}

Aristoteles menggambarkan keutamaan moral sebagai sikap manusia yang membuatnya dapat memilih jalan tengah antara dua ekstrem yang berlawanan. Bagi Aristoteles, keutamaan yang sebenarnya akan terwujud apabila individu dapat bersikap tetap ketika memilih jalan tengah tersebut. Dengan kata lain, jika seseorang mampu memilih jalan tengah hanya karena kebetulan maka ia belum dapat memiliki keutamaan ini (Bertens, 2018:209-210). Keutamaan ini dapat berupa: murah hati, keberanian, tanggung jawab, tulus, rendah hati, keadilan, serta persahabatan.

\section{2) Keutamaan Intelektual}

Keutamaan intelektual terbagi menjadi dua jenis, yakni: kebijaksanaan teoritis sebagai suatu sikap yang mampu mengenali kebenaran, serta kebijaksanaan praktis sebagai suatu sikap yang dapat mengarahkan manusia untuk memilih jalan tengah sesuai dengan keutamaan moral.

\section{Kesejahteraan Psikologis Ryff}

Ryff secara khusus menjelaskan bahwa terdapat enam aspek dalam kesejahteraan psikologis, yakni: penerimaan diri (selfacceptance), hubungan positif dengan orang lain (positive relationship withe others), otonomi (autonomy), penguasaan lingkungan (environmental mastery), tujuan hidup (purpose in life), serta pertumbuhan pribadi (personal growth) (Ryff, 1995 dalam Prabowo, 2016:248). Berikut penjelasan lengkap terkait aspek-aspek tersebut: 


\section{1) Penerimaan Diri (self-acceptance)}

Individu dikatakan telah melakukan penerimaan diri apabila ia secara sadar mengetahui dan menerima segala macam kelebihan maupun kekurangannya, serta merasa positif dengan masa lalunya. Namun, jika individu tersebut masih merasa kecewa dengan masa lalunya dan tidak bisa menerima dirinya apa adanya itu berarti dia belum dapat melakukan penerimaan diri.

2) Hubungan Positif dengan Orang Lain (positive relationship withe others)

Karakteristik individu yang memiliki hubungan positif dengan orang lain, yaitu: adanya kehangatan dan kepuasan, hubungan dibangun dengan pondasi kepercayaan satu sama lain, memperhatikan kesejahteraan orang lain, kesejahteraan psikologi yang dimilikinya kuat, mempunyai afek serta kedekatan, juga dapat memahami aspek saling memberi dan menerima dalam suatu hubungan (Prabowo, 2016:249).

\section{3) Otonomi (autonomy)}

Otonomi adalah kemampuan individu untuk melakukan suatu hal secara mandiri atau terlepas dari ketergantungan dengan orang lain. Dengan demikian, seorang yang memiliki sikap otonomi mampu meneguhkan pendiriannya sekalipun hal itu dianggap berbeda dari norma umum. Ryff menjelaskan bahwa seseorang dapat berfungsi secara penuh (fully functioning person) apabila ia mempunyai perspektif pribadi terkait penilaian diri (internal locus of evaluation) sesuai dengan standar yang ia miliki tanpa harus melibatkan persetujan dari orang lain (Ryff, 1995 dalam Prabowo, 2016:250).

Adapun ciri-ciri individu yang memiliki sikap otonomi, yakni: mandiri, dapat bertahan dalam tekanan sosial untuk berpikir serta bertindak, mampu mengatur tindakannya sesuai dengan yang ada dalam dirinya, juga dapat melakukan evaluasi terkait dirinya tersebut sesuai dengan standar yang ia punya (Prabowo, 2016:250).

\section{4) Penguasaan terhadap Lingkungan (environmental mastery)}

Penguasaan terhadap lingkungan merupakan suatu sikap seorang individu yang mampu mengelola lingkungan sekitarnya dengan penuh daya cipta baik melalui aktivitas fisik ataupun psikis hingga terwujud lingkungan yang sesuai dan dapat memenuhi kebutuhan hidupnya. Individu yang memiliki sikap penguasaan terhadap lingkungan memiliki ciriciri sebagai berikut: menguasai dan berkompeten mengelola lingkungannya, dapat memanfaatkan segala kesempatan secara mangkus, dapat memilih relasi yang cocok dengan kebutuhan serta nilai-nilai personal, juga mampu mengatur aturan yang berasal dari kegiatan eksternal (Prabowo, 2016:250).

5) Tujuan Hidup (purpose in life )

Seseorang yang mempunyai tujuan hidup berarti seorang individu yang mampu menciptakan kesuksesan terkait pencarian makna serta tujuan dalam pelbagai usaha dan kesempatan, sehingga ia sadar bahwa hidupnya berarti. Karakteristik individu yang mempunyai tujuan hidup, yakni: adanya tujuan serta perasaan terarah dalam hidup, merasa yakin bahwa baik kehidupan masa lalu maupun kehidupan sekarang memiliki makna tersendiri, teguh terhadap keyakinannya terkait makna hidup, dan mempunyai sasaran akhir dalam hidupnya (Prabowo, 2016:251).

\section{6) Pertumbuhan Pribadi (personal growth)}

Seorang individu yang sehat seharusnya memiliki kemampuan untuk terus mengembangkan segala potensi diri demi menjadi individu yang utuh. Aktualisasi dan realisasi potensi diri merupakan inti dari perspektif klinis terkait pertumbuhan pribadi. Dengan demikian individu yang mampu mengembangkan dirinya memiliki ciri-ciri, yakni: adanya perasaan terkait perkembangan secara kontinu, dapat memahami dirinya sebagai individu yang tumbuh dan berkembang, bersedia mengalami pengalaman baru, menyadari bahwa segala potensi dirinya akan terealisasi, adanya perubahan sebagai refleksi peningkatan pengetahuan pribadi, serta dapat mengerti perkembangan dan perilaku dirinya sepanjang waktu (Prabowo, 2016:251).

\section{HASIL DAN PEMBAHASAN}

\section{A. Ikigai Kaisar Akihito}

1. Adanya Motivasi dan Bersfiat Pribadi 軍民は入り乱れた沖縄戦は、凄惨を極 め——終結までに、県出身の犠牲者 
は民間人 9 万 4 千人、軍人軍属 2 万 8

千 228 人、上っている。 . （昭和

51 年沖縄県援護課発表)

しかも、天皇の名の下で行われた終戦 後も沖縄は米軍占領下に取り残された まま、講和条約が締結されていた。

二度との裏切り。. 「「本土の捨てて 石にされた」。

沖縄には強烈な怒りがあった。

外間守善：.. 殿下、沖縄ご訪問で

は何が起こるかわかりません

ので、くれぐれもお気を付

けられるよに。. ・

明仁：何が起きても受けます。

明仁天皇太子はこの日が来るずっと以

前から、沖縄の苦灘の歴史に心を寄せ

ていた。昭和 38 年(一九六三年) 4 月

1 日。「沖縄豆記者本土訪問団」東宮

御所訪問。

(明仁天王物語： $162 \sim 163$ )

Gunmin wa irimidareta Okinawa-sen wa, seisan o kiwame Shuuketsu

made ni, ken shusshin no gisei-sha wa minkan hito 9 man 4 sennin, gunjin gunzoku 2 man 8 sen 228-ri,-joutte iru. (Shouwa 51-nen Okinawa-ken engo-ka happyou).

Shikamo, tennou no na no shita de okonawa reta shuusen-go mo Okinawa wa beigun senryou-ka ni torinokosa reta mama, kouwa jouyaku ga teiketsu sarete ita.

Nidoto no uragiri... 'Hondo no sutete ishi ni sareta'.

Okinawa ni wa kyouretsuna ikari ga atta.

Hokama Shuzen :... Denka, Okinawa go houmonde wa nani ga okoru ka wakarimasen node, kureguremo oki o tsukerareru you ni...

Akihito : Naniga okitemo ukemasu.

Akihito ten koutaishi wa kono hi ga kuru zutto izen kara, Okinawa no ku Nada no rekishi ni kokoro o yosete ita. Shouwa 38 nen (1963 nen) shigatsu 1 nichi. 'Okinawa mame kisha hondo houmondan' Touguugosho houmon.

Terjemahan:

Pada saat perang melawan Okinawa, militer dan warga sipil tergabung dampak yang ditimbulkan dari tragedi tersebut sangat dahsyat jumlah korban dari prefektur itu telah meningkat menjadi 94.000 warga sipil dan 28.228 personel militer. (Diumumkan oleh Divisi Dukungan Prefektur Okinawa pada tahun 1976). Ditambah lagi, bahkan setelah perang berakhir atas nama Kaisar, Okinawa ditinggalkan di bawah pendudukan militer Amerika, dan perjanjian damai ditandatangani.

Pengkhianatan lagi.... "Daratan itu dibuang dan diubah menjadi batu."

Terjadi kemarahan yang luar biasa di Okinawa.

Hokama Shuzen : ..... Yang Mulia, saya tidak tahu apa yang akan terjadi pada kunjungan Anda ke Okinawa nanti, karena itu sebisa mungkin tolong Yang Mulia berhati-hati.

Akihito : Saya akan menerimanya apapun yang akan terjadi.

Pangeran Akihito sangat bersimpati dengan sejarah penderitaan Okinawa jauh sebelum hari ini tiba. 1 April 1963 (1963). "Kelompok Kunjungan Reporter Cilik Mame Okinawa" mengunjungi Istana Kekaisaran Tomiya.

(Akihito Tennou Monogatari: 162-163)

Pada kutipan di atas (Akihito Tennou Monogatari: 162-163) ditemukan konsep ikigai berupa karakteristik ikigai menurut Kamiya (1966), yaitu adanya motivasi dan bersifat pribadi. Karakteristik tersebut tercermin dalam perkataan Akihito, "saya akan menerimanya apapun yang akan terjadi". Dari perkataan ini tersirat makna bahwa Akihito memiliki motivasi untuk tetap pergi ke Okinawa meskipun ia tahu sangat berisiko. Kaisar Akihito yang memiliki sifat berkeinginan kuat telah mebulatkan tekad untuk pergi ke Okinawa karena itulah kunjungan ke sana murni berasal dari dirinya bukan atas paksaan atau suruhan orang lain. Hal ini tercermin pada pernyataan yang berbunyi, "Pangeran Akihito sangat bersimpati dengan 
sejarah penderitaan Okinawa jauh sebelum hari ini tiba." Kalimat tersebut secara eksplisit memiliki makna bahwa sebelum berencana melakukan kunjungan ke Okinawa Akihito memang sudah bersimpati dan menaruh perhatian kepada rakyat Okinawa sejak kunjungan Reporter Cilik Mame (mame kisha) yang beranggotakan anak-anak asal Okinawa ke istana kekaisaran.

2. Chiisaku Hajimeru Koto (Awali dari Hal Kecil)

世田谷区の英語教師。山本和昭の熱意

により、沖縄の子供達と皇族の面会が

実現。

これには、皇太子の意向も強く働いた

と言われている。

明仁：出身地はどこですか？

豆記者 1 ：は。. .はい、宮古です。

明仁：平良市はヒララシと読むと

聞きましたが。. 。平

良中学校は何と読むの? 七

ララ中？タイラ中？

豆記者 2 ：（殿下何でそんなことまで ...?)

豆記者 1 ：タ。.タイラ中です。

山本和昭：（殿下は沖縄に深い関心を お持ちだ。.よく 研究していらっさる。)

豆記者 1 ：近い将来_—組国に復帰 したいです！！

相反する想いがあるとはいえ、「本土 復帰」は長く沖縄の悲願であった。

一度きりの特例だった東宮御所訪問だ

が. . . 場所を軽井沢に変え、その後 \& 皇太子一家と沖縄の子供達の

交流は続けていた。

$$
\text { （明仁天王物語：164-165） }
$$

Setagaya ku no eigo kyoushi. Yamamoto Kazuaki no netsui ni yori, Okinawa no kodomodachi to kouzoku no menkai ga jitsugen.

Kore ni wa, koutaishi no ikou mo tsuyoku hataraita to iwa rete iru.

Akihito : Shusshin-chi wa dokodesu ka?

Mame

kisha 1: Wa... Hai, Miyakodesu.

Akihito : Tairashi wa hirarashi to yomu to kiki mashitaga...

Taira chuugakkou wa nanto yomu no? Hirara-chuu? Taira-chuu?

Mame

Kisha 2 : (Denka nande son'na koto made..?)

Mame

Kisha 1: Ta... Taira-chūdesu.

Yamamoto

Kazuaki: (Denka wa Okinawa ni fukai kanshin o o-mochida... Yoku kenkyuu shite irassaru.)

Mame

Kisha 1 : Chikai shourai_gumi koku ni fukki shitaidesu!!

Souhansuru omoi ga aru to wa

ie, 'hondofukki' wa nagaku Okinawa no higandeatta.

Ichido kiri no tokureidatta Touguugosho houmondaga... Basho o karuizawa ni kae, sonogo mo __ Koutaishi ikka to Okinawa no kodomodachi no kouryuu wa tsudzukete ita.

Terjemahan:

Berkat antusiasme Kazuaki Yamamoto, seorang guru bahasa Inggris di wilayah Setagaya. Kunjungan anak-anak Okinawa menemui keluarga kerajaan berhasil terwujud.

Dikatakan pula, berkat kegiatan ini keinginan putra mahkota juga terlaksana.

Akihito : Kamu berasal dari mana? Reporter Cilik

Mame $1 \quad$ :...Iy-iya, Saya dari Miyako.

Akihito : Ku dengar Kota Hirara dibaca "hirarashi", kalau SMP Taira dibacanya apa? SMP Taira?

Reporter Cilik Atau SMP Hirara?

Mame 2 : (Ya ampun, kenapa Yang Mulia sampai segitunya...?)

Reporter Cilik

Mame 1 : Ta-Taira.

Kazuaki

Yamamoto : (Yang Mulia rupanya sangat tertarik pada Okinawa... Pasti beliau sudah banyak belajar.) 
Reporter Cilik

Mame 1 : Dalam waktu dekat ___ Saya ingin (Okinawa) kembali ke dalam (kedaulatan) Jepang!!

Terlepas dari perasaan kontradiksi, "kembali ke daratan" sudah lama menjadi keinginan yang paling didambakan bagi Okinawa.

Pernah sekali waktu ketika kunjungan tersebut akan berlangsung...Tempat tujuannya dialihkan ke Karuizawa, dan setelahnya

Pertukaran antara keluarga putra mahkota dengan anak-anak

Okinawa terus berlanjut.

(Akihito Tennou Monogatari: 164-165)

Pilar ikigai yang tergambar dalam cuplikan manga di atas yaitu, Chiisaku Hajimeru Koto atau Awali dari Hal Kecil. Pilar ini direalisasikan oleh Kaisar Akihito yang pada saat itu masih menjadi putra mahkota melalui sikap hangat dan penuh antusias ketika menerima kunjungan Reporter Cilik Mame. Kaisar Akihito bahkan sampai mengajukan pertanyaan remeh-temeh terkait cara membaca kanji 平良 apakah dibaca "taira" atau "hirara". Pertanyaan Kaisar Akihito itu pun membuat salah satu reporter cilik dan Yamamoto terkejut dan menyadari betapa Kaisar Akihito telah berjuang keras mengumpulkan informasi agar dapat menciptakan percakapan yang familiar dengan anak-anak Okinawa.

3. Jibun kara no Kaihou (Pembebasan Diri)

反日派の

$$
\begin{gathered}
\text { 政治家 : 考え方に違いがあっても } \\
\text { 乗り越えられる、それそ } \\
\text { が英国流立憲主義だ。 } \\
\text { 殿下は幸運な青年です。 } \\
\text { 我々は過去に属している } \\
\text { が. . . あなたは、未来 } \\
\text { を持っておられる。 } \\
\quad \text { : Thank you, sir. } \\
\text { 明仁 } \\
\text { 流暢な英語、折り目正しい } \\
\text { 物腰. . フ プリンス.アキヒトのゲ } \\
\text { ントルな態度、頑なな「反日感情」 } \\
\text { は溶解していった。これを機に扇 } \\
\text { 情的な報道は終息する。一九五三 } \\
\text { 年 } 6 \text { 月 } 2 \text { 日エリザベス女王戴冠式。 }
\end{gathered}
$$

とはいえ、明仁天皇太子の席次は 1

7 番目。"その他大勢”の扱い

であった。

（明仁天王物語：117

$\left.\begin{array}{lll}1 & 1 & 8\end{array}\right)$

Hannichiha no

Seijika : Kangaekata ni chigai ga atte mo nori koe rareru, sore koso ga Igirisuryuurikken shugida.

Denka wa koun na seinen desu. Wareware wa kako ni zokushite iruga...Anata wa, mirai o motte ora reru.

Akihito: Thank you, sir.

Ryuuchouna eigo, orime tadashii monogoshi...Purinsu Akihito no gentoruna taido, katakunana 'hannichi kanjou' wa youkai shite itta. Kore o ki ni senjou-tekina houdou wa shuusoku suru. 1953 Rokugatsu 2 nichi Erizabesu joou taikanshiki. To wa ie, Akihito tenkoutaishi no sekiji wa 17-banme. "Sonota taisei" no atsukaideatta.

Terjemahan :

Politisi

Anti-Jepang : Meskipun ada perbedaan pemikiran, konstitusi gaya Inggris akan mengatasinya. Yang Mulia adalah pemuda yang beruntung. Walaupun, kita terlibat dalam masa lalu (yang tidak baik)... Anda masih memiliki masa depan.

Akihito : Terima kasih, Pak.

Dengan bahasa Inggris yang fasih, serta sikapnya santun...Sikap sopan Pangeran Akihito mampu meluluhkan 'sentimen anti Jepang' yang fanatik. Lewat kesempatan tersebut, liputan sensasional pun berakhir. Pada tanggal 2 Juni 1953 penobatan Ratu Elizabeth dilaksanakan. "Di antara semua orang yang hadir" Pangeran Akihito mendapat kursi urutan ke-17.

(Akihito Tennou Monogatari : 117-

Berdasarkan kutipan di atas dapat disimpulkan bahwa, Kaisar Akihito mampu 
bersikap sejalan dengan pilar ikigai Jibun kara Kaihou atau Pembebasan Diri. Hal ini dibuktikan dengan kemampuan Kaisar Akihito untuk bersikap profesional di hadapan para politikus anti Jepang. Alih-alih ikut membalas sikap sentimen mereka dengan perilaku serupa, Kaisar Akihito memilih untuk tetap menghormati dan bersikap sopan di hadapan mereka. Sikap gentle Kaisar Akihito tersebut ia tunjukkan melalui kemampuan bahasa Inggrisnya yang mumpuni disertai keramahtamahan.

4. Chouwa to Jizoku Kanousei (Keselarasan dan Kesinambungan)

午後 1 時過ぎ、車列が系満市に入

ってすぐ、沿道の白銀病院病室の

空から、石やガラス瓶、角材など

が、投げ込まれる。訪問反対する

青年達の犯行であった。 . .

明仁：石ぐらい、投げられてもい

い. . .そうしたことに恐れずに、

県民の中に入っていきたい。

同日、午後 1 時 20 分頃、皇太子

夫妻「ひめゆりの塔」

「ひめゆり同空会」会長源ゆき子 夫妻がその説明に耳を傾けていた、 まさにその時壕に潜んでい

た「沖縄解放同盟準備会」の青年

二名が火炎瓶を投擲。

明仁：源さん！！

ケガ人はなかったが現場は混乱に

陷った。いわゆる「ひめゆりの塔

事件」である。

(明仁天王物語：16 8〜171)

Gogo ichi ji sugi, sharetsu ga Itoman

shi ni haitte sugu, endou no shiro

gane byouin byoushitsu no mado kara, ishi ya garasubin, kakuzai nado ga, nagekomareru. Houmon hantai suru seinen-tachi no hankoudeatta...

Akihito : Ishi gurai, nage rarete mo ii...

Soushita koto ni osorezu ni, kenmin no naka ni haitte ikitai. Doujitsu, gogo ichi ji ni juu pun goro, koutaishi fusai 'hime yuri no tou' touchaku.

'Hime yuri dōsōkai' kaichou

Minamoto Yukiko Fusai ga sono

setsumei ni mimi o katamukete ita, masani sonotoki_ Gou ni

hisonde ita 'Okinawa kaihou doumei

junbi-kai' no seinen ni mei ga kaenbin

o touteki.

Akihito : Minamoto san!!

Kega hito wa nakatta ga genba wa

konran ni ochiitta. Iwayuru

'himeyurinotou jiken' dearu.

Terjemahan:

Pukul 1 siang lewat, ketika iringiringan mobil memasuki Kota Itoman, di sepanjang jalannya batu, botol kaca, balok kayu dan lain-lain bertebaran dilemparkan dari kamar Rumah Sakit Shirogane. Hal ini merupakan tindak kriminal dari para pemuda yang menentang kunjungan (Akihito dan Permaisuri Michiko) tersebut.

Akihito : Tidak masalah kalau sampai dilempar batu...

Di hari yang sama, pukul 1.20 siang, putra mahkota dan permaisuri tiba di "Tugu Himeyuri". Pada saat putra mahkota dan permaisuri tengah mendengar penjelasan dari ketua "Asosiasi Alumni Himeyuri", Minamoto Yukiko, di saat yang sama....

Dua orang pemuda dari "Komite Persiapan Aliansi Pembebasan Okinawa" yang bersembunyi di parit melempar botol api.

Akihito : Minamoto san !!

Tidak ada orang yang terluka tapi, tempat kejadian menjadi kacau. Kejadian ini kemudian dikenal dengan "Insiden Tugu Himeyuri".

(Akihito Tennou Monogatari : 168-171)

Cuplikan manga di atas menggambarkan konsep ikigai berupa pilar Chouwa to Jizoku Kanousei atau Keselarasan dan Kesinambungan (Mogi, 2018:40). Dalam cuplikan tersebut terlihat Akihito dan Michiko tengah melakukan kunjungan ke Okinawa tepatnya di wilayah Tugu Himeyuri lalu dilanjutkan menuju Balai Kuro Mizuumi dan beberapa tempat lain. Walaupun telah terjadi kericuhan dalam Insiden Tugu Himeyuri, Kaisar Akihito tetap melanjutkan kunjungan tanpa merubah jadwal. 
Tindakan yang dilakukan Kaisar Akihito ini selaras dan berksesinambungan dengan ucapannya bahwa ia akan tetap mengunjungi Okinawa apapun yang terjadi sejalan dengan perkataannya berikut :

$$
\begin{aligned}
& \text { 外間守善：。. 殿下、沖縄ご訪問 } \\
& \text { では何が起こるかわかり } \\
& \text { ませんので、くれぐれもお気を付けら } \\
& \text { れるよ } \\
& \text { に. . } \\
& \text { 明仁：何が起きても受けます。 } \\
& \text { (明仁天王物語：162) }
\end{aligned}
$$

Hokama

Shuzen :... Denka, Okinawago houmonde wa nani ga okoru ka wakarimasen node, kureguremo o ki o tsukerareru you ni...

Akihito :Nani ga okitemo ukemasu.

Terjemahan :

Hokama

Shuzen : ...... Yang Mulia, saya tidak tahu apa yang akan terjadi pada kunjungan Anda ke Okinawa nanti, karena itu sebisa mungkin tolong Yang Mulia berhati-hati. Akihito : Saya akan menerimanya apapun yang akan terjadi.

(Akihito Tennou Monogatari : 162)

5. Chiisana Yorokobi (Kegembiran dari Hal-Hal

$$
\text { Kecil) }
$$

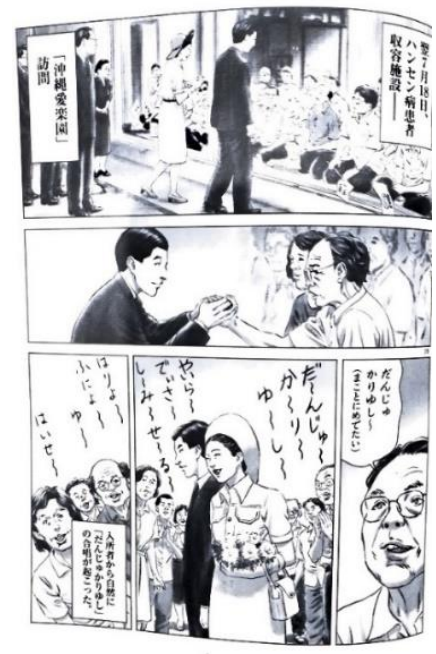

Gambar 1 Kunjungan ke Okinawa Airakuren
翌 7 月 18 日、ハンセン病患者収

容施設「沖縄愛楽園」

患者：だんじゅかりゆし〜（まこ

$$
\text { とにめでたい) }
$$

入所者から自然に「だんじゅかり

ゆし」の合唱が起った。

$$
\text { （明仁天王物語：175) }
$$

Yoku 7 gatsu 18 nichi, hansenbyou kanja shuuyou shisetsu 'Okinawaairakuen'

Kanja : Danju Kariyushi (makoto ni medetai)

Nyuushosha kara shizen ni danjukariyushi' no gasshou ga okotta.

Terjemahan :

Keesokan harinya pada tanggal 18 Juli, di fasilitas akomodasi pasien penyakit kusta "Okinawa Airakuren" Pasien : Danju Kariyushi (saya benar-benar bahagia)

Para pasien tersebut tanpa aba-aba menyanyikan'Danjukariyushi'dalam suatu paduan suara.

(Akihito Tennou Monogatari : 175)

Cuplikan di atas menceritakan Akihito dan Michiko yang tengah mengunjungi fasilitas kesehatan untuk para penderita penyakit kusta di Okinawa. Berdasarkan gambar, Akihito dan Michiko tampak menikmati kunjungan tersebut dengan perasaan senang ketika para pasien mulai bernyanyi Danju Kariyushi sebagai lagu sambutan untuk kedatangan mereka. Konsep ikigai yang ditemukan di sini terkait dengan pilar ikigai, kebahagiaan dari hal-hal kecil. Hal ini terbukti dari ekspresi Akihito yang terlihat bahagia ketika berjabat tangan dengan salah seorang pasien dan menikmati lagu Danju Kariyushi. Sumber kebahagiaan Akihito tersebut bisa dibilang bukanlah suatu hal yang besar, tetapi hal sederhana yang mungkin dianggap remeh oleh orang lain yakni bisa menghabiskan waktu dengan santai serta damai bersama-sama.

6. "Ima Koko" ni Iru Koto (Hadir di Tempat dan

\section{Waktu Sekarang)}

平成 6 年(一九九四年) 2 月 12 日 両陛下の戦地慰霊の旅は、硫黄島 


\author{
訪問から始まっている。とりわけ \\ 戦争の禍の激しかった土地に思い \\ を寄せていくつりでいます。 \\ （『天王陛下誕生日前会見』平成 \\ 6 年)
}

$$
\text { (明仁天王物語：1 } 8 \text { 2) }
$$

Heisei 6 nen (1994) 2 gatsu 12 nichi

Ryou heika no senchi irei no tabi wa, Ioujima houmon kara hajimatte iru.

"Toriwake sensou no wazawai no

hageshikatta tochi ni omoi o yosete

iku tsumori de imasu. "

("Tennou heika tanjoubi zen kaiken"

Heisei 6 nen)

Terjemahan :

Tanggal 12 Februari tahun ke-6

Heisei (1994) Perjalanan ziarah ke

situs Perang Dunia II Kaisar Akihito

dan Permaisuri Michiko dimulai dari

kunjungan ke Iwo Jima.

"Saya memang berniat untuk mem-

perhatikan tempat-tempat

terdampak Perang Dunia II"

(Akihito)

("Wawancara Ulang Tahun Kaisar" tahun ke-6 Heisei)

(Akihito Tennou Monogatari : 182)

Kegitan kunjungan ziarah yang dilakukan oleh Akihito menyiratkan bahwa, ia hadir di tempat dan di waktu sekarang. Bencana Perang Dunia II telah terjadi di masa lalu, tidak ada satu kekuatan pun yang mempu mengubah masa lalu, oleh karena itu targedi perang bukanlah suatu hal yang harus disesalkan tetapi merupakan hal yang wajib dikenang dan diambil pelajarannya demi masa depan yang lebih baik.

\section{B. Ikigai Kaisar Akihito dan Kebahagiaan Eudaimonis}

Pertama-tama perlu diketahui terlebih dahulu apa virtue dari seorang kaisar sebagai pemimpin negara. Virtue dari seorang kaisar adalah menjadi pemimpin yang sebaik-baiknya dengan bersikap adil dan senantiasa mampu merangkul seluruh rakyatnya dalam kondisi apapun tanpa terkecuali.

Adapun karakteristik Ikigai pada Kaisar Akihito yakni, adanya motivasi dan bersifat pribadi. Motivasi dan kemauan pribadi berperan sebagai langkah awal bagi seseorang yang ingin mengaktualisasikan virtue-nya untuk mencapai kebahagiaan eudaimonis. Karena, apabila orang tersebut tidak memiliki motivasi dan berlandaskan keterpaksaan maka virtue yang ingin diaktualisasikan tidak akan terwujud dengan baik.

Pengaktualisasian virtue tersebut juga didukung oleh adanya virtue ethics berupa keberanian Kaisar Akihito untuk mengunjungi Okinawa meskipun dapat membahayakan dirinya, serta keadilan, di mana kunjungan itu dimaksudkan agar penduduk Okinawa tidak merasa terasing di negeri sendiri karena mereka tetap menjadi bagian dari Jepang walau masih dalam pendudukan Amerika. Selain itu, virtue ethics lain yang diwujudkan oleh Kaisar Akihito adalah tanggung jawab. Kala itu Kaisar Akihito memang belum dibaiat sebagai kaisar dan statusnya masih menjadi putra mahkota meskipun demikian, ia tetap sadar kehadirannya ditengah-tengah masyarakat Okinawa adalah tanggung jawabnya untuk mencapai keutaman (virtue) sebagai calon kaisar di masa depan.

Mengaktualisasikan virtue tidak melulu dimulai dengan melakukan hal-hal besar tetapi, dapat pula dilakukan melalui hal kecil atau sederhana seperti tindakan Kaisar Akihito ketika menerima kunjungan Repoter Cilik Mame yang selaras dengan pilar ikigai Chiisaku Hajimeru Koto (Awali dari Hal Kecil). Dalam rangka mengaktualisasikan virtue-nya sebagai kaisar yang mampu merangkul seluruh rakyatnya, Kaisar Akihito banyak belajar dan mengumpulkan informasi terkait Okinawa. Tindakannya ini dimaksudkan agar dapat menciptakan susana akrab dan menyenangkan bersama dengan anak-anak dari Okinawa. Beliau bahkan sampai menanyakan hal sepele mengenai cara membaca kanji kepada kepada delegasi dari Okinawa tersebut yang sampai membuat salah satu anak dan guru yang pendamping mereka terkejut mengapa pertanyaan semacam itu tidak luput dari perhatian Kaisar Akihito. Sementara itu, virtue ethics Kaisar Akihito saat menerima kunjungan Reporter Cilik Mame yaitu persahabatan yang berusaha dijalin antara dirinya dan anak-anak Okinawa.

Melalui pilar ikigai Jibun kara no Kaihou atau pembebasan diri membuat seseorang mampu menerima setiap kekurangan dan kelebihan terkait kemampuan yang ia miliki. 
Hidupnya juga lebih ringan karena mampu melepas kekecewaan ataupun dendam masa lalu. Kaisar Akihito sadar bahwa dirinya tidak mampu untuk merubah kenyataan bahwa, Jepang di masa lampu pernah melakukan kejahatan kemanusian yang fatal. Sehingga, beliau mamaklumi keberadaan golongan anti Jepang yang masih belum bisa menerimanya dengan baik tanpa membalas sikap sentimen mereka. Kaisar Akihito meyakini satu-satunya hal yang bisa dilakukannya adalah selalu bersikap baik dan ramah pada siapa saja bahkan kepada golongan anti Jepang sekalipun.

Selain itu, beliau juga menyadari kedudukannya hanya sebatas simbol persatuan Jepang sehingga tidak memiliki kekuasaan politik yang besar. Melalui kesadaran atas kekurangannya itu, Kaisar Akihito tetap berusaha mengaktualisasikan virtue-nya dengan menggunakan perannya sebagai diplomat sebaik mungkin demi menjalin hubungan baik dengan negara lain ataupun membangun kembali kepercayaan dengan negara-negara yang dulu pernah menjadi musuh Jepang semasa Perang Dunia II. Tindakan Kaisar Akihito tersebut mencerminkan virtue ethics persahabatan serta ketulusan. Hal ini terbukti dengan sikapnya yang selalu ramah dan hangat kepada siapapun tanpa mengingkari kenyataan bahwa dahulu Jepang memang pernah membuat kesalahan yang mungkin tidak akan pernah bisa dimaafkan.

Pilar ikigai Chouwa to Jizoku Kanousei atau keselarasan dan kesinambungan antara ucapan dan tindakan juga berperan ketika seseorang yang hendak mengaktualisasikan virtue-nya. Virtue tidak akan bisa terwujud apabila niatan aktualisasi tersebut hanya direalisasikan lewat ucapan, tetapi harus diwujudkan pula oleh tindakan. Hal ini tercermin dalam kunjungan Kaisar Akihito ke Okinawa yang benar-benar dilaksanakan bukan sekedar omongan belaka. Adapun virtue ethics yang berusaha Kaisar Akihito aktualisasikan dalam kunjungannya ke Okinawa yakni berupa keberanian, keadilan, dan tanggung jawab.

Keberhasilan kunjungan ke Okinawa Airakuren membuat Kaisar Akihito memperoleh kebahagiaan eudaimonisnya melalui kegembiran dari hal-hal kecil. Sambutan hangat yang diterima oleh Kaisar Akihito membuat ia bisa dengan leluasa menikmati waktu bersama para pasien dan memberikan dukungan morel untuk mereka. Melalui tindakan tersebut, Kaisar Akihito dapat dikatakan telah berhasil merangkul rakyatnya di Okinawa sesuai dengan virtue-nya sebagai kaisar. Ketika seseorang telah mengaktualisasikan virtue atau keutamaan miliknya lewat tindakan yang tepat maka ia akan merasakan kebahagiaan. Hal tersebut sesuai dengan perkataan Aristoteles :

...perbuatan yang sejalan dengan

keutamaan pada hakikatnya menyenangkan. Namun selain menyenangkan perbuatan tersebut juga baik dan mulia.

(Aristoteles, 2020: 79)

Sehingga dapat disimpulkan bahwa, dengan menjalankan perbuatan sesuai keutamaan atau virtue, seseorang akan merasa bahagia. Tak hanya bahagia, perbuatan yang sejalan dengan virtue pastilah suatu perbuatan yang mulia. Hal ini sesuai dengan kebahagiaan Kaisar Akihito yang ia peroleh ketika merealisasikan virtue-nya lewat kunjungan ke Okinawa Airakuren. Selain sebagai wujud realisasi dari keutamaan seorang kaisar, kunjungan itu pun merupakan kegiatan yang mulia karena Kaisar Akihito memberikan dukungan morel untuk para pasien agar selalu semangat dan tidak menyerah dengan keadaan.

Kegitan kunjungan ziarah yang dilakukan oleh Akihito menyiratkan bahwa, ia hadir di tempat dan waktu sekarang. Bencana Perang Dunia II telah terjadi di masa lalu, tidak ada satu kekuatan pun yang mempu mengubah masa lalu, oleh karena itu targedi perang bukanlah suatu hal yang harus disesalkan tetapi merupakan hal yang wajib dikenang dan diambil pelajarannya demi masa depan yang lebih baik.

Pilar ikigai "Ima Koko" ni Iru Koto (Hadir di Tempat dan Waktu Sekarang) membuat seseorang mampu meletakkan dirinya di masa kini tanpa menyesali secara berlebihan masa lalu dan bisa menjadikan peristiwa negatif di masa lampau sebagai pijakannya menyongsong masa depan merupakan pertanda bahwa individu tersebut dapat bertindak sesuai virtue-nya. Karena melakukan kegiatan berdasarkan keutamaan atau virtue haruslah berorientasi menuju masa depan. Apabila ia terus-menerus menyesali masa lampau tanpa 
bergerak maju menjadikannya pribadi yang terhambat dan tidak berkembang, alhasil virtue miliknya pun tidak bisa dijalankan dengan baik. Namun sebaliknya, jika seorang individu terus melaju ke arah masa depan tanpa memperhatikan kesalahannya di masa lalu, ia bisa jadi hanya akan mengulang kesalahan yang sama karena ia tak menganggap kesalahannya di masa lalu sebagai pelajaran, tapi sekedar angin lalu saja.

\section{Ikigai Kaisar Akihito dan Kesejahteraan Psikologis}

1. Adanya Motivasi dan Bersifat Pribadi

Karakteristik ikigai berupa adanya motivasi dan bersifat pribadi sesuai dengan dimensi kesejahteraan psikologis yakni, tujuan hidup (purpose of life) dan otonomi (autonomy). Di mana tujuan hidup seorang kaisar tentunya adalah untuk mengayomi rakyatnya baik saat kondisi senang maupun sulit. Tujuan ini diwujudkan dalam pelbagai kunjungan yang Kaisar Akihito lakukan ke tempat-tempat yang dilanda bencana atau musibah. Salah satunya yaitu, kunjunan ke Okinawa. Dalam kunjungan tersebut Kaisar Akihito memerikan dukungan morel kepada para korban bencana. Tujuan hidup tentunya tidak akan mampu terlaksana apabila tidak disertai dengan motivasi yang mendasarinya.

Sementara itu, sikap otonomi ditunjukkan oleh Kaisar Akihito lewat tindakannya dengan duduk berlutut di hadapan para korban bencana gunung meletus di Nagasaki terlepas dari aturan kekaisaran yang tidak memperbolehkannya. Melalui tindakan tersebut Akihito bisa dikatakan berhasil mengambil keputusan sendiri (otonomi) tanpa pengaruh orang lain walaupun harus bertentangan dengan norma-norma kekaisaran yang ada. Hal ini sesuai dengan penjelasan Ryff bahwa seseorang dapat berfungsi secara penuh (fully functioning person) apabila ia mempunyai perspektif pribadi terkait penilaian diri (internal locus of evaluation) sesuai dengan standar yang ia miliki tanpa harus melibatkan persetujan dari orang lain (Ryff, 1995 dalam Prabowo, 2016).

2. Chiisaku Hajimeru Koto (Awali dari Hal Kecil)

Kaisar Akihito mulai membangun relasi dengan anak-anak Okinawa lewat sikapnya yang hangat dan penuh antusias ketika menyambut kunjungan mereka di Karuizawa. Pilar ikigai Chiisaku Hajimeru Koto atau Awali dari Hal Kecil yang tercermin dalam tindakan Kaisar Akihito tersebut terkait dengan aspek kesejahteraan psikologis yakni, hubungan positif dengan orang lain (positive relationship with others ).

Adanya hubungan positif antara Kaisar Akihito dengan anak-anak Okinawa terjalin lewat suasana hangat serta bersahabat yang diberikan oleh Kaisar Akihito kepada anak-anak tersebut begitupun sebaliknya. Hal ini terlihat pada sikap Kaisar Akihito yang berusaha mendekatkan diri dengan menanyakan kepada salah satu anak dari kota mana ia berasal. Kemudian, beliau melanjutkan pertanyaannya terkait topik yang sangat familiar bagi anak-anak Okinawa yaitu, cara membaca kanji 平良 apakah dibaca "hirara" atau "taira". Mendengar pertanyaan-pertanyaan dari Kaisar Akihito tadi, seorang anak laki-laki asal Okinawa meskipun sedikit gugup akhirnya menjawab dengan penuh semangat.

\section{Jibun kara no Kaihou (Pembebasan Diri)}

Pembebasan diri berhubungan dengan aspek penerimaan diri atau self acceptence serta pertumbuhan pribadi atau personal growth. Pembebasan diri secara paradoks terkait dengan penerimaan diri. Kita dianggap telah melakukan pembebasan diri ketika telah menerima diri kita apa adanya dan membuang segala bentuk khayalan diri yang ada pada diri kita (Mogi, 2018:37). Seseorang yang telah melakukan penerimaan diri salah satunya ditandai dengan kemampuan bersikap positif dengan masa lalunya.

Penerimaan diri (self acceptence) Kaisar Akihito terbukti melalui sikapnya yang ramah dan tetap menghormati para politisi anti Jepang di Inggris alih-alih ikut bersikap sentimen. Tidakan Kaisar Akihito tersebut sejalan dengan karakteristik dari penerimaan diri yakni, mampu bersikap positif terhadap masa lalu. Kaisar Akihito mampu menyikapi dengan baik pertikaian yang melibatkan Jepang dan Inggris di masa lalu sebagai pembelajaran dan berusaha membangun kembali hubungan baik dengan kedua negara tersebut. Melalui tindakan itu pula Kaisar Akihito secara tidak langsung mencirikan pribadi yang terus berkembang (personal growth), 
karena beliau menyadari bahwa seseorang tidak akan bisa berkembang kehidupannya apabila ia berlarut-larut menyesali masa lalu tanpa bertindak lebih jauh ke depan.

4. Chouwa to Jizoku Kanousei (Keselarasan dan Kesinambungan)

Pilar ikigai keselarasan dan kesinambungan terkait dengan aspek tujuan hidup (purpose in life) dalam teori kesejahteraan psikologis. Keselarasan dan kesinambungan antara ucapan dan tingkah laku tentunya diperlukan apabila hendak meralisasikan tujuan hidup. Tujuan hidup akan terlaksana jika ucapan dan tingkah laku selaras dan berkesinambungan. Bila seseorang hanya mampu berbicara mengenai tujuan hidupnya tanpa melaksanakannya, maka tujuan hidup itu tidak akan tercapai.

Sebagaimana yang telah dibahas sebelumnya, Kaisar Akihito tidak hanya menjadikan ucapannya untuk tetap pergi ke Okinawa sebagai omong kosong belaka terlepas dari segala risiko yang mungkin nanti akan ia dapatkan. Ucapan tersebut benar-benar ia buktikan melalu tindakan nyata lewat kunjungannya ke Okinawa.

\section{Chiisana Yorokobi (Kegembiran dari Hal-Hal Kecil)}

Kegembiraan dari hal-hal kecil yang tampak pada Kaisar Akihito dalam manga Akihito Tennou Monogatari yaitu, kegembiraan menghabiskan waktu bersama dengan damai bersama rakyatnya seperti yang tegambar pada kunjungan ke Okinawa Airakuren. Dalam kunjungan itu, Kaisar Akihito tampak senang bisa diterima dengan baik oleh para pasien di sana meskipun ketika kunjungan pertamannya ke Okinawa ia harus menerima perlakukan tak menyenangkan dari pihak yang bersikap sentimen.

Chiisana yorokobi atau kegembiraan dari hal-hal kecil pada Kaisar Akihito sejalan dengan aspek hubungan positif dengan orang lain atau positive relationship with others. Hubungan positif tersebut tercermin pada relasi antara Kaisar Akihito dengan rakyatnya dalam hal ini para pasien kusta di Okinawa Airakuren. Baik Kaisar Akihito maupun para pasien, mereka semuanya mampu menciptakan suasana yang hangat dan bersahabat. Para pasien bahkan tanpa aba-aba secara serentak menyanyikan lagu khas Okinawa Danju Kariyushi sebagai sambutan atas kedatangan Kaisar Akihito beserta Permaisuri Michiko. Dalam kunjungan tersebut juga tampak Kaisar Akihito mampu berbaur dengan para pasien tanpa canggung, beliau pun menyempatkan diri menggenggam tangan salah satu pasien sebagai simbolisme dukungannya kepada mereka.

\section{6. "Ima Koko" ni Iru Koto (Hadir di Tempat dan Waktu Sekarang)}

Sikap Kaisar Akihito terkait dengan pilar ikigai hadir di tempat dan waktu sekarang tercermin melalui pelbagai kunjungan ziarah ke situs peringatan Perang Dunia II di Jepang maupun di luar negeri. Tindakan tersebut berhubungan dengan aspek penerimaan diri (self acceptence) serta penguasaan terhadap lingkungan (environmental mastery).

Kaisar Akihito mampu bersikap positif dengan permasalahan masa lalunya tanpa terikat dengan masa lalu tersebut melalui sikap hadir di waktu sekarang. Hal ini sejalan dengan aspek penerimaan diri, yang mana salah satu karakteristik penerimaan diri pada seseorang yaitu kemampuan menerima masa lalu secara positif.

Di sisi lain, Kaisar Akihito juga dapat memanfaatkan dengan baik kunjungan ziarahnya ke pelbagai daerah terdampak perang untuk membangun kembali kepercayaan terhadap dirinya sebagai pemimpin negara begitupun terhadap Jepang yang sempat runtuh akibat kejamnya Perang Dunia II. Melalui kunjungan tersebut, dapat disimpulkan bahwa Kaisar Akihito memiliki kemampuan menguasai lingkungannya dengan mengelola setiap kesempatan demi menciptakan linkungan yang sesuai.

\section{KESIMPULAN}

Kaisar Akihito sebagai seorang pemimpin negara memiliki ikigai menjadi kaisar yang baik melalui kemampuannya untuk merangkul rakyatnya tanpa terkecuali serta menjalin persahabatan dengan dunia internasional. Wujud ikigai tersebut didukung oleh karakteristik ikigai menurut Kamiya (2004) yakni, adanya motivasi dan bersifat pribadi. Kemudian diperkuat pula dengan kelima pilar 
ikigai menurut Mogi (2018) yaitu, Chiisaku Hajimeru Koto (Awali dari Hal Kecil), Jibun kara no Kaihou (Pembebasan Diri), Chouwa to Jizoku Kanousei (Keselarasan dan Kesinambungan), Chiisana Yorokobi (Kegembiran dari Hal-Hal Kecil), juga "Ima Koko" ni Iru Koto (Hadir di Tempat dan Waktu Sekarang).

Karakteristik serta pilar ikigai yang ditunjukkan oleh Kaisar Akihito sejalan pula dengan kebahagiaan eudaimonis dan kesejahteraan psikologis. Kebahagiaan eudaimonis menurut Aristoteles dapat dicapai apabila individu mampu mengaktualisasikan virtue-nya.

Adapun virtue seorang kaisar yaitu menjadi kaisar yang baik dengan kemampuan merangkul seluruh rakyatnya serta menjalin hubungan baik dengan berbagai negara di dunia. Melalui tindakan yang telah ditunjukkan oleh Kaisar Akihito dapat disimpulkan bahwa, beliau telah berhasil menjalankan hidupnya sesuai virtue-nya sebagai kaisar.

Sementara itu, ikigai yang dimiliki Kaisar Akihito juga mencerminkan enam aspek kesejahteraan psikologis Ryff yakni, penerimaan diri (self-acceptance), hubungan positif dengan orang lain (positive relationship withe others), otonomi (autonomy), penguasaan lingkungan (environmental mastery), tujuan hidup (purpose in life), serta pertumbuhan pribadi (personal growth).

\section{DAFTAR PUSTAKA}

Arif, I. S. (2016). Psikologi Positif Pendekatan Saintifik Menuju Kebahagiaan. Jakarta: Gramedia Pustaka Utama.

Aristoteles. (2020). Etika Nikomakea, terj. Ratih Dwi Astuti. Yogyakarta: BASABASI.

Bertens, K. (2018). Sejarah Filsafat Yunani. Sleman: KANISIUS.

Bilash, O. (2016). Study Abroad, Transformation, and Ikigai: A Case Study. FIRE: Forum for International Research in Education, 5(2): 245-260 doi: 10.32865/fire201952170.

Eller, R. (2016). Ikigai and Higher Education: A Review of The Literature. Assumption University-e Journal of Interdisciplinary Research (AU-eJIR),
1(2):50-51. Retrieved from http://www.assumptionjournal.au.edu /index.php/eJIR/article/view/4278.

Jusmiati. (2017). Konsep Kebahagiaan Martin Seligman: Sebuah Penelitian Awal Rausyan Fikr, 13(2):359-374 doi:10.24239/rsy.v13i2.270.

Kamiya, M. (2004). Ikigai ni Tsuite. Tokyo: Misuzu Bookstore.

Mogi, K. (2018). The Book of IKIGAI, terj. Nuraini Mastura. Jakarta Selatan: Penerbit Naura.

Park, Y. (2015). Sense of Ikigai (reason of living) and Social Support in Asia-Pasific Region. Behavlormatrika, 42(2):191-208 doi: 10.2333/BHMK.42.191.

Prabowo, A. (2016). Kesejahteraan Psikologis Remaja di Sekolah. Jurnal Ilmiah Psikologi Terapan, 4(2): 246-260. doi: 10.22219/jipt.v4i2.3527.

Ramadhani, T., Djunaedi, \& S., A. S. (2016). Kesejahteraan Psikologis (Psychological Well-Being) Siswa yang Orang Tuanya Bercerai (Studi Deskriptif yang Dilakukan pada Siswa SMK Negeri Pembangunan Jakarta). Insight: Jurnal Bimbingan Konseling, 5(1):108-115 doi: 10.21009/INSIGHT.051.16.

Ratna, N. K. (2015). Teori, Metode, dan Teknik Penelitian Sastra. Yogyakarta: Pustaka Pelajar.

Ryff, C. D. (1989). Happiness is Everything or, is it? Journal of Personality and Social Psychology, 57(6):1069-1081 doi: 10.1037/0022-3514.57.6.1069.

Ryff, C. D., \& Keyes, C. L. (1995). The Structures of Psychological Well-Being Revisited. Journal of Personality and Social Psychology, 69(4):719-727 doi: 10.1037/0022-3514.69.4.719.

Seligman, M. E., \& Csikszentmihalyi, M. (2000). Positive Psychology An Introduction. The American Psychological Association Inc, 55(1):5-14 doi: $10.1037 / 0003-066 X .55 .1 .5$.

Snyder, C. R., \& Lopez, S. J. (2002). Handbook of Psychology Positive. Oxford: Oxford University Press.

Tjahjadi, S. P. (2004). Petualangan Intelektual. Sleman: KANISIUS.

Tumanggor, R. O. (2016). Perbedaan antara Pendekatan Hedonis dan Eudaimonis Atas Quality of Life: Kajian Filosofis. Prosiding Forum Ilmiah Psikologi Indonesia Fakultas Psikologi Universitas 
Tarumanegara, (pp. 341-354). Jakarta doi: 10.31219/osf.io/bk8c3.

Yulanda, A. (2020). Implementasi Virtue Ethics Aristoteles di Era Kekinian. Jurnal AlAqidah: Jurnal Ilmu Aqidah Filsafat, 12(1):90-104

doi: $10.15548 /$ ja.v12i1.1570.

\section{PUSTAKA LAMAN}

Abdulsalam, H. (2018). Akihito, Kaisar Jepang Nyeleneh yang Cinta Sains dan Ikan Gobi. Retrieved from https://tirto.id/akihitokaisar-jepang-nyeleneh-yang-cintasains-dan-ikan-gobi-c5jm (10 Maret 2020)

BBC News Indonesia. (2019). Kaisar Akihito turun takhta, pertama dalam 200 tahun sejarah kekaisaran. Retrieved from https://www.bbc.com/indonesia/duni a-48101061 (10 Maret 2020)

Firman, T. (2019). Retrieved from https://tirto.id/lengsernya-akihitokaisar-jepang-yang-palin-sering-mintamaaf-dnkf (10 Maret 2020)

Ikigaitribe. (2019). Ikigai According To Professor Akihiro Hasegawa. Retrieved from https://ikigaitribe.com/ikigai/podcast0 1/ (8 Maret 2021)

Suastha, R. D. (2017). Akihito, Kaisar Reformis yang Dicintai Rakyat Jepang. Retrieved from

https://www.cnnindonesia.com/intern asional/20171201175439-113-

259526/akihito-kaisar-reformis-yang-

dicintai-rakyat-jepang (29 juni 2020) 